УДК 338.23

\title{
СТРАТЕГИЯ УСТОЙЧИВОГО РАЗВИТИЯ ЭНЕРГЕТИКИ РЕСПУБЛИКИ БЕЛАРУСЬ: АНАЛИЗ И ОСНОВНЫЕ ТЕНДЕНЦИИ
}

\author{
Т.Г. ЗОРИНА \\ канд. экон. наук, докторант, \\ доцент кафедры логистики и ценовой политики \\ Белорусского государственного экономического университета
}

Аннотация

В статье проведен кластерный анализ 149 стран мира и выделены 12 кластеров по уровню энергетического потенциала данных стран. На основе изучения программно-нормативных документов, характеризующих их политику в области энергетики, определень стратегии каждой страны в области устойчивого развития отрасли. $C$ помощью дискриминантного анализа выявлено соответствие стратегий устойчивого развития энергетическому потенциалу исследуемых стран. Выделены проблемы в области энергетической политики и предложены пути по ее совершенствованию. Определены основные направления реализации стратегии устойчивого развития энергетики Республики Беларусь.

Ключевые слова: энергетика, устойчивое развитие, энергетический потенцииал.

\section{Abstract}

The article deals with the cluster analysis of 149 countries and runs about 12 clusters from the point of the energy potential of these countries. The strategies of each country in the field of sustainable energy development are revealed on the basis of the relevant documents analysis. By means of the discriminant analysis the compliance of the strategies to the energy potential of the countries is defined. The author determines problems in the field of power policy and offers the ways of its improvement. The main trends of realization of sustainable energy development strategy in the Republic of Belarus are defined.

Keywords: energy, sustainable development, energy potential.

\section{ВВЕДЕНИЕ}

В мировой энергетике можно выделить следующие направления энергетического развития на перспективу: 1) снижение доли нефти и угля и повышение доли природного газа и низкоуглеродных источников 
в валовом энергопотреблении; 2) развитие ВИЭ и атомной энергии; 3) разработка инновационных технологий; 4) снижение выбросов; 5) повышение энергоэффективности и уровня доступа к современным энергоносителям.

В ходе реализации данных направлений ведущие страны мира все более широко используют концепцию устойчивого развития при формировании своей энергетической политики.

Для достижения устойчивого развития энергетики странами могут использоваться различные стратегии.

Автором была выдвинута гипотеза о том, что существуют группы стран со схожим уровнем развития определенных факторов, для которых применение определенного набора стратегий достижения устойчивого развития энергетики является наиболее характерным.

\section{РЕЗУЛЬТАТЫ И ИХ ОБСУЖДЕНИЕ}

Выбор перспективных стратегий достижения устойчивого развития энергетики Республики Беларусь на основе анализа мирового опыта. К числу факторов, которые предопределяют возможность использования той или иной стратегии достижения устойчивого развития энергетики, можно отнести следующие: 1) уровень экономического развития (показатель - ВВП на душу населения в тыс. долл. США); 2) размер выбросов загрязняющих веществ в атмосферу (показатель - выбросы $\mathrm{CO}_{2}$ в т на душу населения); 3) уровень электрификации (показатель - доля населения, имеющего доступ к электрической энергии в \%); 4) уровень запасов энергоресурсов (показатель - доля использования собственных ископаемых энергоресурсов (угля, природного газа и нефти) при производстве электрической энергии в \%).

Для анализа указанных показателей была собрана информация по 149 странам за 2010 г. Источниками послужили статистические данные Всемирного Банка [9], МЭА [8], World-Statistics.org [10].

Для выделения групп стран со схожим уровнем развития выше указанных факторов использовался метод иерархического кластерного анализа. Мерой сходства был выбран квадрат евклидова расстояния. На основе анализа шагов агломерации было определено, что оптимальным для классификации данной совокупности является 12 кластеров. Для разделения стран на кластеры использовался программный пакет SPSS.

C целью упрощения интерпретации результатов количественные характеристики факторов, использованных в анализе, были разделены на 3 категории, характеризующими низкое, среднее и высокое значение, таблица 1. 


\section{Таблица 1 - Классификационные признаки стран}

\begin{tabular}{|c|c|c|c|c|}
\hline Характеристика & $\begin{array}{c}\text { Уровень } \\
\text { экономического } \\
\text { развития (ВВП на } \\
\text { душу населения) }\end{array}$ & $\begin{array}{c}\text { Размер выбросов } \\
\text { загрязняющих } \\
\text { веществ в } \\
\text { атмосферу } \\
\text { (выбросы } \mathrm{CO}_{2} \text { на } \\
\text { душу населения) }\end{array}$ & $\begin{array}{c}\text { Уровень } \\
\text { электрификации } \\
\text { (доля населения, } \\
\text { имеющего доступ } \\
\text { к электрической } \\
\text { энергии) }\end{array}$ & $\begin{array}{c}\text { Уровень запасов } \\
\text { энергоресурсов } \\
\text { (доля } \\
\text { использования } \\
\text { собственных } \\
\text { ископаемых } \\
\text { энергоресурсов } \\
\text { (угля, } \\
\text { природного газа } \\
\text { и нефти) при } \\
\text { производстве } \\
\text { электрической } \\
\text { энергии) }\end{array}$ \\
\hline Низкий & Менее 34,003 & Менее 13,457 & Менее 39 & Менее 33,33 \\
\hline Средний & $34,003-68,007$ & $13,457-26,883$ & $39-69,5$ & $33,33-66,67$ \\
\hline Высокий & Более 68,007 & Более 26,883 & Более 69,5 & Более 66,67 \\
\hline
\end{tabular}

Результаты кластеризации представлены в таблице 2.

Таблица 2 - Характеристики кластеров

\begin{tabular}{|c|c|c|c|c|c|c|}
\hline \multirow[b]{2}{*}{ 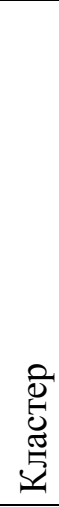 } & \multicolumn{4}{|c|}{ Характеристики } & \multirow{2}{*}{ 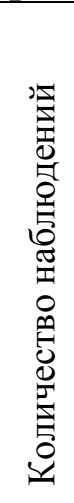 } & \multirow[b]{2}{*}{ Страны } \\
\hline & 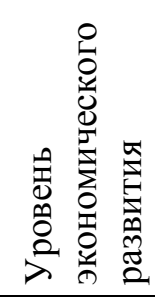 & 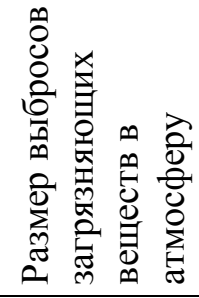 & 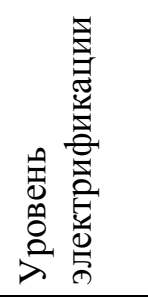 & 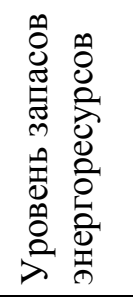 & & \\
\hline 1 & 2 & 3 & 4 & 5 & 6 & 7 \\
\hline 1 & Низкий & Низкий & Средний & $\begin{array}{l}\text { Низкий } \\
\text { либо } \\
\text { средний }\end{array}$ & 8 & $\begin{array}{l}\text { Ангола, Камерун, Пакистан, Намибия, Гана, } \\
\text { Габон, Сенегал, Йемен }\end{array}$ \\
\hline 2 & Низкий & Низкий & Низкий & $\begin{array}{l}\text { Низкий } \\
\text { либо } \\
\text { средний }\end{array}$ & 14 & $\begin{array}{l}\text { Афганистан, Бенин, Камбоджа, Эфиопия, } \\
\text { Мадагаскар, Замбия, Буркина Фасо, } \\
\text { Эритрея, Гаити, Мадагаскар, Малави, } \\
\text { Судан, Того, Уганда }\end{array}$ \\
\hline
\end{tabular}


Окончание таблицы 2

\begin{tabular}{|c|c|c|c|c|c|c|}
\hline 1 & 2 & 3 & 4 & 5 & 6 & 7 \\
\hline 3 & $\begin{array}{l}\text { Низкий } \\
\text { либо } \\
\text { средний }\end{array}$ & Низкий & Высокий & Низкий & 56 & $\begin{array}{l}\text { Албания, Беларусь, Бельгия, Армения, } \\
\text { Австрия, Барбадос, Бутан, Бразилия, } \\
\text { Бурунди, Коста-Рика, Хорватия, Куба, } \\
\text { Кипр, Доминика, Доминиканская } \\
\text { Республика, Сальвадор, Эквадор, } \\
\text { Финляндия, Франция, Гамбия, Гренада, } \\
\text { Грузия, Гватемала, Гайана, Гондурас, } \\
\text { Гонконг, Исландия, Ирландия, Италия, } \\
\text { Ямайка, Япония, Иордания, Республика } \\
\text { Корея, Кыргызстан, Латвия, Ливан, } \\
\text { Мавритания, Литва, Мальта, Маврикий, } \\
\text { Молдова, Марокко, Непал, Никарагуа, } \\
\text { Папуа Новая Гвинея, Парагвай, Португалия, } \\
\text { Республика Словакия, Сингапур, Испания, } \\
\text { Шри-Ланка, Суринам, Швеция, } \\
\text { Таджикистан, Турция, Уругвай }\end{array}$ \\
\hline 4 & Низкий & Низкий & $\begin{array}{l}\text { Высокий } \\
\text { либо } \\
\text { средний }\end{array}$ & Высокий & 35 & $\begin{array}{l}\text { Аргентина, Греция, Чехия, Польша, Китай, } \\
\text { Россия, Новая Зеландия, Сербия, } \\
\text { Азербайджан, Алжир, Бангладеш, Боливия, } \\
\text { Босния и Герцеговина, Ботсвана, Чили, } \\
\text { Колумбия, Кот-д'Ивуар, Египет, Индонезия, } \\
\text { Индия, Иран, Македония, Мексика, } \\
\text { Монголия, Бирма, Черногория, Нигер, } \\
\text { Нигерия, Перу, Румыния, ЮАР, } \\
\text { Туркменистан, Узбекистан, Украина, } \\
\text { Вьетнам }\end{array}$ \\
\hline 5 & $\begin{array}{l}\text { Низкий } \\
\text { либо } \\
\text { средний }\end{array}$ & Низкий & Высокий & Средний & 13 & $\begin{array}{l}\text { Болгария, Германия, Венгрия, Ирак, } \\
\text { Словения, Венесуэла, Соединенное } \\
\text { Королевство, Израиль, Малайзия, } \\
\text { Филиппины, Тайланд, Сирия, Тунис, }\end{array}$ \\
\hline 6 & Средний & Средний & Высокий & Высокий & 4 & Австралия, Канада, США, ОАЭ \\
\hline 7 & Низкий & Средний & Высокий & $\begin{array}{l}\text { Высокий } \\
\text { либо } \\
\text { средний }\end{array}$ & 6 & $\begin{array}{l}\text { Бахрейн, Оман, Казахстан, Саудовская } \\
\text { Аравия, Бруней Даруссалам, Эстония }\end{array}$ \\
\hline 8 & Высокий & $\begin{array}{l}\text { Низкий } \\
\text { либо } \\
\text { средний } \\
\end{array}$ & Высокий & Низкий & 2 & Люксембург, Швейцария \\
\hline 9 & Низкий & Низкий & Низкий & Высокий & 5 & $\begin{array}{l}\text { Мозамбик, Зимбабве, Танзания, } \\
\text { Демократическая Республика Конго, } \\
\text { Республика Конго }\end{array}$ \\
\hline 10 & $\begin{array}{l}\text { Средний } \\
\text { либо } \\
\text { Низкий }\end{array}$ & Высокий & Высокий & Высокий & 2 & Кувейт, Тринидад и Тобаго \\
\hline 11 & $\begin{array}{l}\text { Высокий } \\
\text { либо } \\
\text { средний }\end{array}$ & Низкий & Высокий & Высокий & 3 & Дания, Нидерланды, Норвегия \\
\hline 12 & Высокий & Высокий & Высокий & Высокий & 1 & Катар \\
\hline
\end{tabular}


Для определения стратегий достижения устойчивого развития энергетики, используемых исследуемыми странами, были изучены нормативно-правовые акты и программные документы в области энергетической политики этих стран. В результате чего были выделены наиболее типичные стратегии достижения устойчивого развития энергетики. К ним относятся:

1) электрификация;

2) энергосбережение;

3) расширение и модернизация энергоисточников;

4) использование местных ископаемых энергоресурсов;

5) использование энергоэффективных технологий;

6) снижение выбросов $\mathrm{CO}_{2}$;

7) использование ВИЭ;

8) энергобезопасность;

9) использование атомной энергии;

10) реструктуризация отрасли;

11) диверсификация энергоресурсов и энергоисточников.

Для анализа была составлена база данных, содержащая используемые исследуемыми странами стратегии достижения устойчивого развития энергетики в разрезе кластеров.

С целью построения иерархической структуры стратегий достижения устойчивого развития энергетики использовался метод анализа круга проблем, который заключается в установлении взаимосвязи «причинаследствие». На рисунке 1 представлены 3 уровня стратегий.

Как видно рисунка 1, все стратегии достижения устойчивого развития энергетики взаимосвязаны между собой. К стратегиям нулевого уровня относятся использование ВИЭ, использование атомной энергии, использование местных ископаемых энергоресурсов, реструктуризация отрасли. Они могут использоваться для реализации стратегий более высоких уровней и имеют один выход. Стратегии нулевого уровня напрямую участвуют в реализации стратегий первого уровня. Также они опосредованно участвуют в реализации стратегий второго уровня. К стратегиям достижения устойчивого развития энергетики первого уровня относятся использование энергоэффективных технологий, диверсификация энергоресурсов и энергоисточников, расширение и модернизация энергоисточников. Они имеют в качестве входа стратегии нулевого уровня, а в качестве выхода - стратегии второго уровня. К стратегиям второго уровня относятся электрификация, снижение выбросов $\mathrm{CO}_{2}$, энергобезопасность, энергосбережение. Стратегии этого уровня имеют один вход от стратегий первого уровня. 


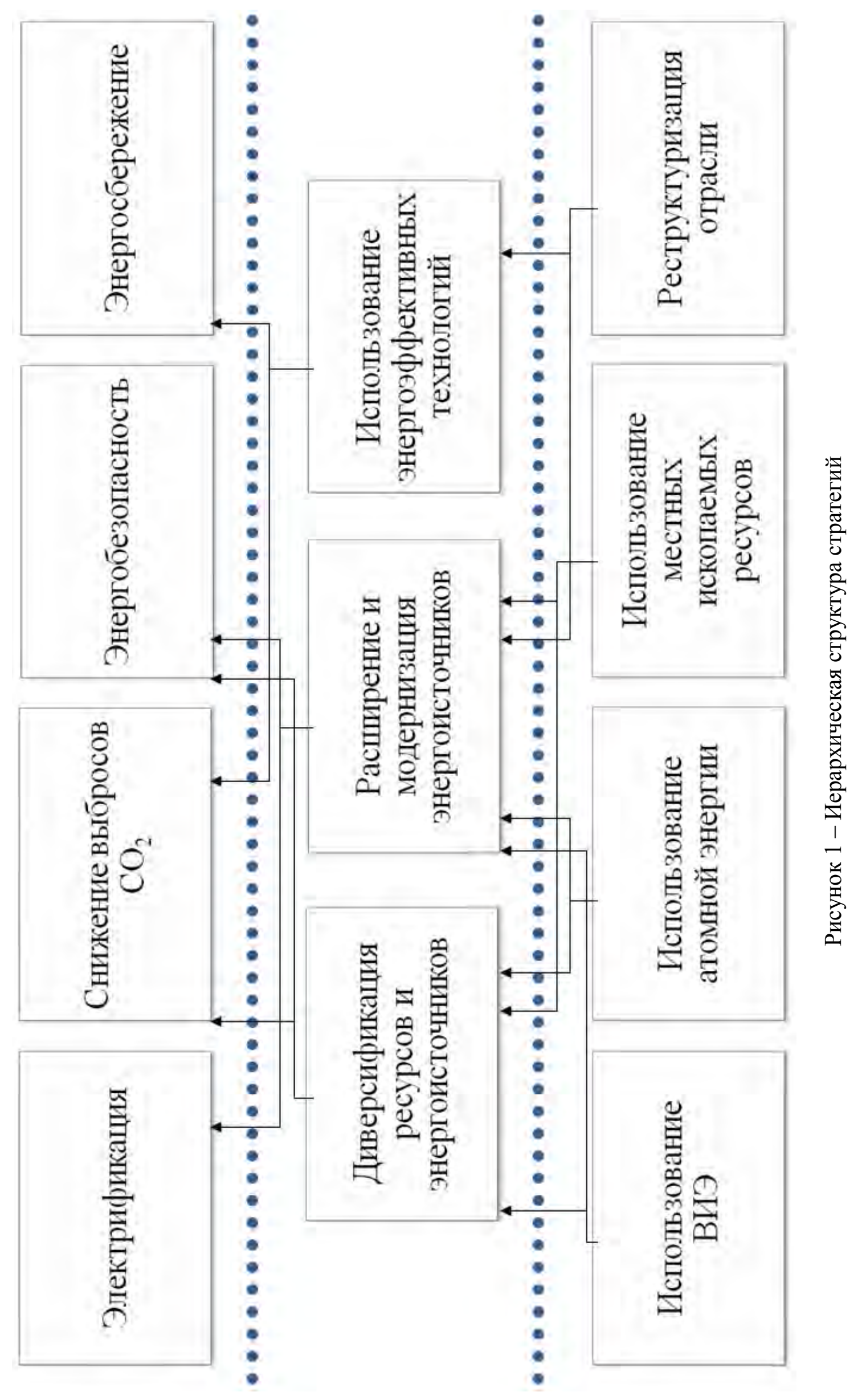


При формировании энергетической политики различные страны выделяют стратегии достижения устойчивого развития энергетики, относящиеся к различным уровням, по-разному. Некоторые страны перечисляют стратегии всех трех уровней при формировании своей энергетической политики, включая стратегические цели и пути их достижения.

В связи с различными подходами стран к формулировкам стратегий стратегии достижения устойчивого развития энергетики в дальнейшем анализе было принято решение об использовании всей совокупности перечисленных ранее стратегий.

С целью проверки гипотезы о наличии характерных для каждого кластера стратегий был использован множественный дискриминантный анализ. В качестве зависимой переменной выступила принадлежность страны к кластерам, а в качестве предикторов (независимых переменных) используемые странами стратегии достижения устойчивого развития энергетики.

Целью дикриминантного анализа являлось выявление соответствий между выделенными на основе характеристик стран (уровень экономического развития; размер выбросов загрязняющих веществ в атмосферу; уровень электрификации; уровень запасов энергоресурсов) кластерами и определенными на основе дискриминантных функций группами стран по набору применяемых ими стратегий достижения устойчивого развития энергетики. Совпадение кластеров и дискриминантных групп позволит сделать вывод о наличии взаимосвязями между характеристиками стран и используемых ими стратегий достижения устойчивого развития энергетики.

При построении модели использовался прямой метод, который предполагает включение всех предикторов в модель. Выполнение дискриминантного анализа осуществлялось с помощью программного пакета SPSS. В результате чего были получены 11 дискриминантных функций.

В таблице 3 представлены собственные значения канонических дискриминантных функций и процент объясняемой ими дисперсии.

Таблица 3 - Собственные значения канонических дискриминантных функций

\begin{tabular}{|c|r|r|r|r|}
\hline Функция & $\begin{array}{c}\text { Собственное } \\
\text { значение }\end{array}$ & $\begin{array}{c}\text { \% } \\
\text { объясненной } \\
\text { дисперсии }\end{array}$ & Кумулятивный \% & $\begin{array}{c}\text { Каноническая } \\
\text { корреляция }\end{array}$ \\
\hline 1 & 0,891 & 46,5 & 46,5 & 0,686 \\
\hline 2 & 0,314 & 16,4 & 62,8 & 0,489 \\
\hline
\end{tabular}




Окончание таблицы 3
\begin{tabular}{|c|r|r|r|r|}
\hline Функция & $\begin{array}{c}\text { Собственное } \\
\text { значение }\end{array}$ & $\begin{array}{c}\text { \% } \\
\text { объясненной } \\
\text { дисперсии }\end{array}$ & Кумулятивный \% & $\begin{array}{c}\text { Каноническая } \\
\text { корреляция }\end{array}$ \\
\hline 3 & 0,272 & 14,2 & 77,0 & 0,462 \\
\hline 4 & 0,159 & 8,3 & 85,3 & 0,371 \\
\hline 5 & 0,107 & 5,6 & 90,9 & 0,311 \\
\hline 6 & 0,077 & 4,0 & 95,0 & 0,268 \\
\hline 7 & 0,053 & 2,7 & 97,7 & 0,224 \\
\hline 8 & 0,029 & 1,5 & 99,2 & 0,169 \\
\hline 9 & 0,008 & 0,4 & 99,7 & 0,090 \\
\hline 10 & 0,007 & 0,3 & 100,0 & 0,081 \\
\hline 11 & 0,000 & 0,0 & 100,0 & 0,010 \\
\hline
\end{tabular}

Нормированные коэффициенты канонической дискриминантной функции и процент дисперсии, объясненной данной функцией, позволяют оценить, какие стратегии являются наиболее часто используемыми в некотором числе стран. Далее наиболее часто используемые определенными странами стратегии расположены в порядке убывания по частоте. Как следует из таблицы 3, 46,5\% исследуемых стран отдают предпочтение таким стратегиям, как электрификация, снижение выбросов, использование ВИЭ (Гонконг, Индонезия и др.). Для 16,4\% отличительными являются стратегии использования местных энергоресурсов, электрификации и снижения выбросов (Бангладеш, Нигер и др.). 14,2\% стран широко применяют такие стратегии как использование ВИЭ, энергоэффективных технологий и энергосбережения (Индия, Сальвадор и др.). 8,3\% исследуемых стран характеризуется совокупностью использования стратегий снижения выбросов, реструктуризации энергетики и использования атомной энергетики (Малави, Вьетнам и др.). Только 5,6\% стран отдают предпочтение стратегиям энергобезопасности, реструктуризации энергетики и энергосбережения (Российская Федерация, Босния и Герцеговина и др.). Такие стратегии, как энергосбережение, модернизация и расширение энергоисточников, энергобезопасность характерны для 4,0\%. анализируемых стран (Туркменистан, США и др.). $2,7 \%$ исследуемых стран ориентированы на использование ВИЭ, реструктуризацию энергетики и энергосбережение (Австралия, Болгария и др.). Только $1,5 \%$ стран отличаются использованием стратегий атомной энергии, снижения выбросов, энергоэффективных технологий (Венгрия, Великобритания).

В таблице 4 представлены коэффициенты классифицирующих функций. Коэффициенты классифицирующей функции Фишера можно напрямую использовать для классификации. Для каждой группы создается 
отдельный набор коэффициентов, при этом наблюдение относится к группе, которой соответствует наибольшее значение дискриминантной функции.

Для первой группы наиболее характерными являются такие стратегии достижения устойчивого развития энергетики, как электрификация, энергоэффективные технологии, использование ВИЭ, реструктуризация отрасли. Средний уровень электрификации стран данной группы стимулирует государства принимать меры в данном направлении. В то же время, страны первого кластера характеризуются низким либо средним уровнем запасов энергоресурсов, что, в свою очередь, объясняет стремление данной группы стран использовать потенциал ВИЭ как альтернативу ископаемым видам топлива, применять энергоэффективные технологии для снижения затрат на энергию и реструктурировать энергетику для повышения эффективности её функционирования.

Страны второй группы наибольший приоритет отдают таким стратегиям достижения устойчивого развития энергетики, как электрификация, модернизация и расширение энергоисточников, использование ВИЭ. Низкий уровень электрификации стран данного кластера способствует рассмотрению стратегии электрификации в качестве одной из наиболее приоритетных стратегий для этих стран. Низкий уровень электрификации данных стран, с одной стороны, и низкий либо средний уровень запасов энергоресурсов, с другой стороны, заставляет эти государства использовать ВИЭ и модернизировать и расширять энергоисточники для решения проблем, связанных с удовлетворением энергетических нужд.

Для стран третьей группы наиболее часто используемыми являются использование энергоэффективных технологий и ВИЭ. Необходимо отметить, что третий кластер является самым многочисленным из всех. К нему принадлежат 56 стран, что обуславливает достаточно большую степень разнородности данных стран по уровню экономического развития (от низкого до среднего). Однако низкий уровень запасов энергоресурсов стимулирует страны данной группы внедрять энергоэффективные технологии для снижения затрат на энергию и использовать ВИЭ как альтернативу ископаемым видам топлива.

Страны четвертой группы ориентированы на повышение уровня электрификации, применение энергоэффективных технологий, снижение выбросов, использование ВИЭ, реструктуризацию отрасли. Члены данной группы относятся ко второму по численности кластеру (включает 35 стран), что является причиной достаточно высокой разнородности данных стран. Эти страны характеризуются средним либо высоким уровнем электрификации. Для стран со средним уровнем электрификации 
приоритетным является расширение доступа к электрической энергии. Несмотря на низкий уровень выбросов загрязняющих веществ в атмосферу, страны данного кластера продолжают ориентироваться на дальнейшее снижение выбросов. Это обусловлено в первую очередь тем, что в состав данного кластера входит большое количество европейских стран (Чехия, Польша, Греция и др.), которые в своей энергетической политики ориентируются на директивы ЕС по повышению эффективности функционирования европейской энергосистемы. Имея высокий уровень запасов, эти страны, тем не менее, нацелены на использование ВИЭ, внедрение энергоэффективных технологий и реструктуризацию энергетики для сохранения этих запасов.

Такие стратегии достижения устойчивого развития энергетики, как энергоэффективные технологии, снижение выбросов, использование ВИЭ, диверсификация энергоресурсов и энергоисточников, находят наиболее частое применение в пятой группе. Средний уровень запасов энергоресурсов заставляет данные страны диверсифицировать существующие источники для снижения рисков, связанных с обеспечением топлива для энергетики. Хотя страны данного кластера имеют низкий размер выбросов по сравнению с другими кластерами, они нацелены на дальнейшее их снижение. Применение энергоэффективных технологий и использование ВИЭ являются достаточно типичными стратегиями для стран, пытающихся решить, с одной стороны, проблему снижения выбросов, с другой стороны, обеспечить удовлетворение потребности в энергии при небольших собственных запасах энергоресурсов.

Страны шестой группы в большой степени нацелены на модернизацию и расширение энергоисточников, использование местных энергоресурсов, энергоэффективных технологий, снижение выбросов, использование ВИЭ, диверсификацию энергоресурсов и энергоисточников. Высокий уровень запасов собственных энергоресурсов стран данного кластера, с одной стороны, позволяет им максимально использовать местные энергоресурсы, с другой стороны, заставляет диверсифицировать существующие источники и ориентироваться на модернизацию и расширение энергоисточников для эффективного использования собственных запасов. Страны шестого кластера характеризуются средним уровнем выбросов, что является причиной рассмотрения стратегии снижения выбросов в качестве одной из приоритетных. В данном случае использование ВИЭ и применение энергоэффективных технологий в высокой степени служит и экологическим целям. 
Для стран седьмой группы наиболее характерными являются использование местных энергоресурсов, применение энергоэффективных технологий и использование ВИЭ. Для стран данного кластера характерен высокий либо средний уровень запасов, что, с одной стороны, стимулирует использование местных энергоресурсов, с другой стороны, заставляет искать пути внедрения ВИЭ для снижения зависимости от ископаемых видов топлива (как например, в Омане и Бахрейне) либо для высвобождения местных энергоресурсов для поставок на экспорт (что характерно для Саудовской Аравии).

Страны восьмой группы отдают предпочтение таким стратегиям достижения устойчивого развития энергетики, как энергосбережение, энергоэффективные технологии, снижение выбросов, использование ВИЭ, энергобезопасность, диверсификация энергоресурсов и энергоисточников. Во многом применение выше указанных стратегий связано с тем, что страны восьмого кластера при высоком уровне экономического развития обладают низким уровнем запасов энергоресурсов, что заставляет их искать пути укрепления энергонезависимости страны. Рациональной является стратегия снижения выбросов, так как страны восьмого кластера характеризуются низким или средним размеров выбросов. В то же время необходимо отметить, что одна (Люксембург) из двух стран восьмого кластера принадлежит к ЕС и для нее устанавливаются определенные требования по энергоэффективности и увеличению доли ВИЭ в структуре энергетики.

Электрификация, энергоэффективные технологии, снижение выбросов, использование ВИЭ являются наиболее типичными стратегиями для стран девятой группы. Одной из самых серьезных проблем в области энергетики является повышение уровня электрификации стран данного кластера. Несмотря на наличие низкого размера выбросов загрязняющих веществ в атмосферу, эти страны учитывают экологические аспекты в своей энергетической политике. Страны данного кластера имеют высокий уровень запасов энергоресурсов, однако ВИЭ используются, с одной стороны, для повышения электрификации отдаленных и сельскохозяйственных районов (как например, в Мозамбике), с другой стороны, для сокращения зависимости от ископаемых видов топлива (например, в Танзании) [7]. 


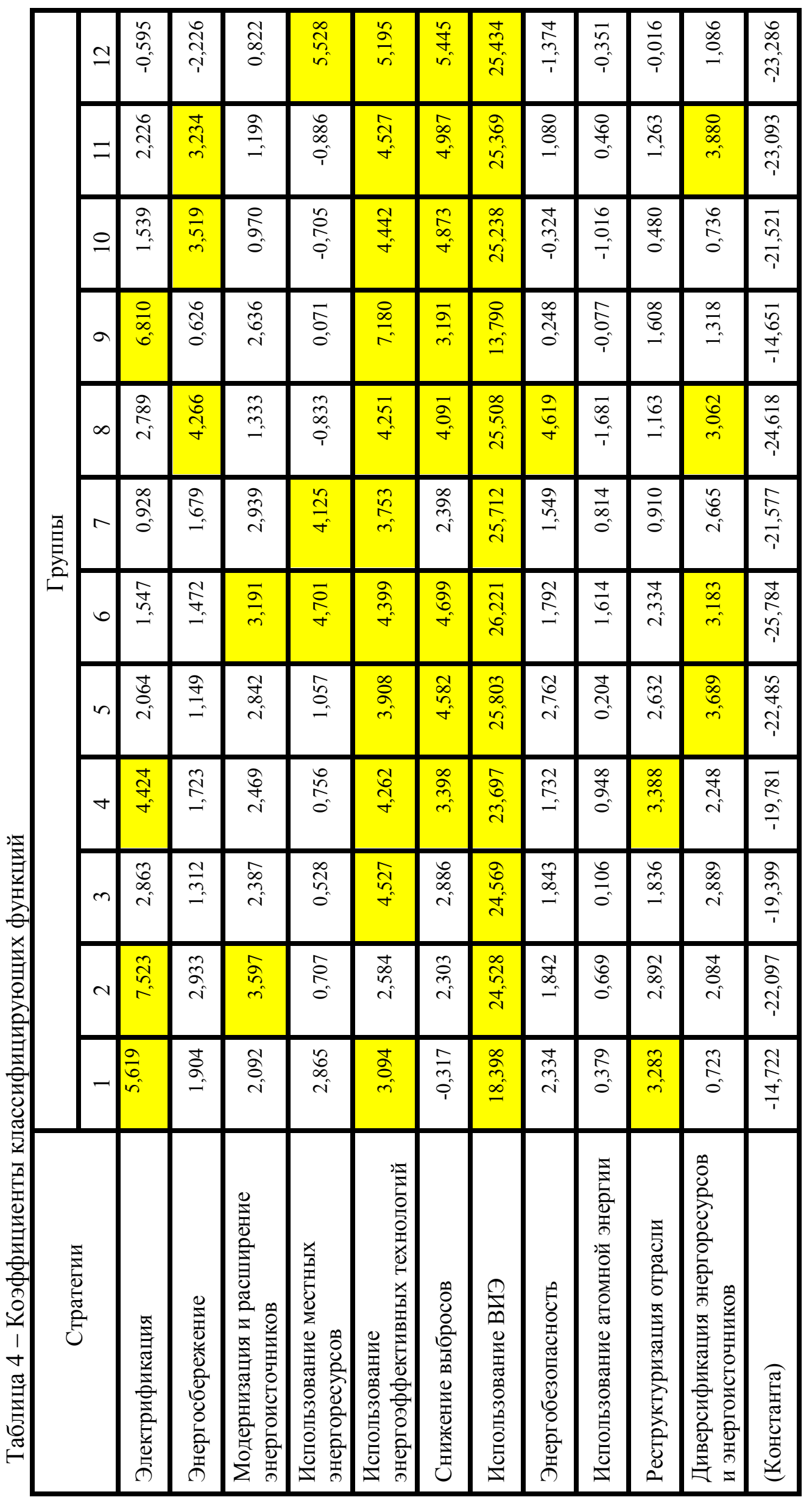


Такой набор стратегий достижения устойчивого развития энергетики, как энергосбережение, энергоэффективные технологии, снижение выбросов, использование ВИЭ, наиболее часто применяют страны десятой дискриминантной группы. Страны данного кластера характеризуются высоким уровнем запасов энергоресурсов, однако использование ВИЭ обусловлено их стремлением снизить потребление ископаемых видов топлива. По причине высокого уровня выбросов загрязняющих веществ в атмосферу стратегия снижения выбросов является крайне необходимой для этих стран. С учетом низкого либо среднего уровня экономического развития страны десятого кластера ориентируются не только на внедрение энергоэффективных технологий, являющихся по своей сути достаточно дорогостоящей мерой, но и на энергосбережение для удовлетворения потребности в продукции энергетики.

Страны одиннадцатой группы в большей степени используют энергосбережение, энергоэффективные технологии, снижение выбросов, использование ВИЭ и диверсификацию энергоресурсов и энергоисточников. Страны данного кластера характеризуются высоким уровнем запасов энергоресурсов, низким уровнем выбросов, высоким либо средним уровнем экономического развития. 2 из 3 стран данного кластера входят в ЕС, по этой причине увеличение доли ВИЭ, снижение выбросов, повышение энергоэффективности являются для них обязательными целями энергетической политики. В то же время необходимо отметить, что Норвегия, не являясь членом ЕС, также участвует в системе торговли квотами на выбросы парниковых газов в ЕС и во время переговоров с ЕС взяла определенные обязательства по увеличению доли ВИЭ в структуре энергетики [7].

Для двенадцатой группы характерны такие стратегии достижения устойчивого развития энергетики, как использование местных энергоресурсов, энергоэффективные технологии и снижение выбросов, использование ВИЭ. Высокий уровень запасов энергоресурсов способствует использованию местных энергоресурсов. В то же время для двенадцатого кластера характерен высокий уровень экономического развития, что позволяет финансировать внедрение энергоэффективных технологий и ВИЭ. Высокий уровень выбросов является причиной рассматривать стратегию снижения выбросов загрязняющих веществ в атмосферу как одну из основных для данного кластера.

$\mathrm{B}$ соответствии с коэффициентами классифицирующей функции Фишера, все стратегии достижения устойчивого развития энергетики были проранжированы по уровню значимости для исследуемых стран. На первом месте оказалась стратегия использования ВИЭ (максимальный 
коэффициент - 26,221), на втором - электрификация (максимальный коэффициент - 7,523), на третьем - энергоэффективные технологии (максимальный коэффициент - 7,180), на четвертом - использование местных энергоресурсов (максимальный коэффициент - 5,528), на пятом снижение выбросов (максимальный коэффициент - 5,445), на шестом энергобезопасность (максимальный коэффициент - 4,619), на седьмом энергосбережение (максимальный коэффициент - 4,266), на восьмом диверсификация энергоресурсов и энергоисточников (максимальный коэффициент - 3,880), на девятом - модернизация и расширение энергоисточников (максимальный коэффициент - 3,597), на десятом реструктуризация энергетики (максимальный коэффициент - 3,388), на одиннадцатом - использование атомной энергии (максимальный коэффициент - 1,614).

Что касается атомной энергии, в 2011 г. наметилась тенденция к снижению использования данной стратегии достижения устойчивого развития энергетики. В частности, такие страны, как Бельгия, Германия предусматривают сокращение использования атомной энергии в рамках своей энергетической политике, что связано с аварией на АЭС Фукусима-1 в Японии в 2011 г. В тоже время 20,8\% исследуемых стран (Намибия, Словакия, Монголия, Болгария, Канада и др.) планируют расширять использование атомной энергии.

Состав дискриминантных групп представлен в таблице 5.

Сопоставив соотнесение стран по кластерам и дискриминантным группам (таблицы 2 и 5) можно сделать вывод о неполном совпадении результатов кластерного и дискриминантного анализа: Таким образом, не все страны обладающие сходными характеристиками, используют одинаковые стратегии в рамках устойчивого развития энергетики.

Для сопоставления предсказанной принадлежности групп к кластерам была составлена таблица 6.

Как следует из таблицы 6, страны, принадлежащие к 6, 8, 10 и 12 кластерам были на 100\% правильно классифицированы с помощью дискриминантных функций, то есть они придерживаются стандартных для их кластера стратегий. Наименьшее число правильно классифицированных стран, принадлежит к 4 кластеру - 22,86\%. 


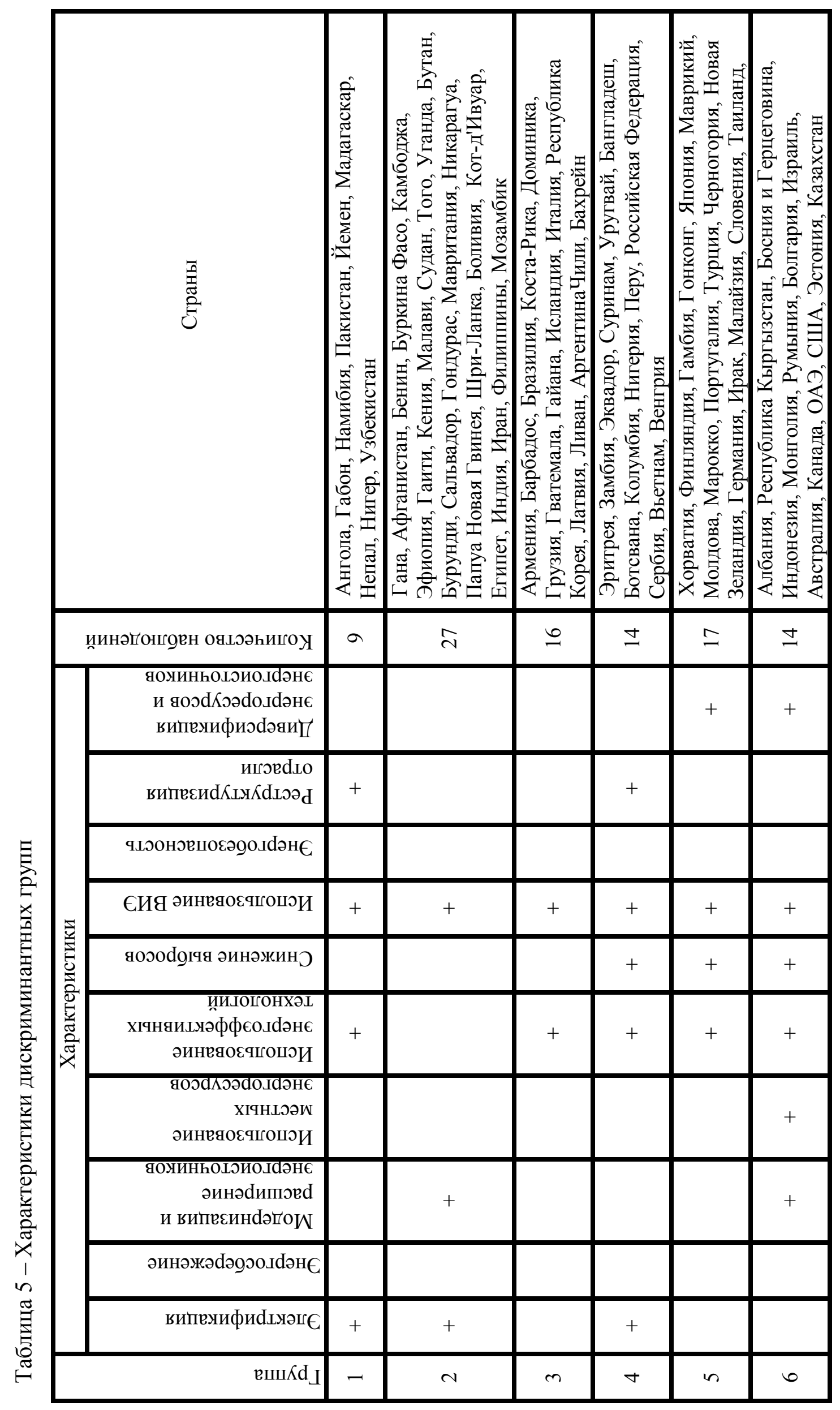




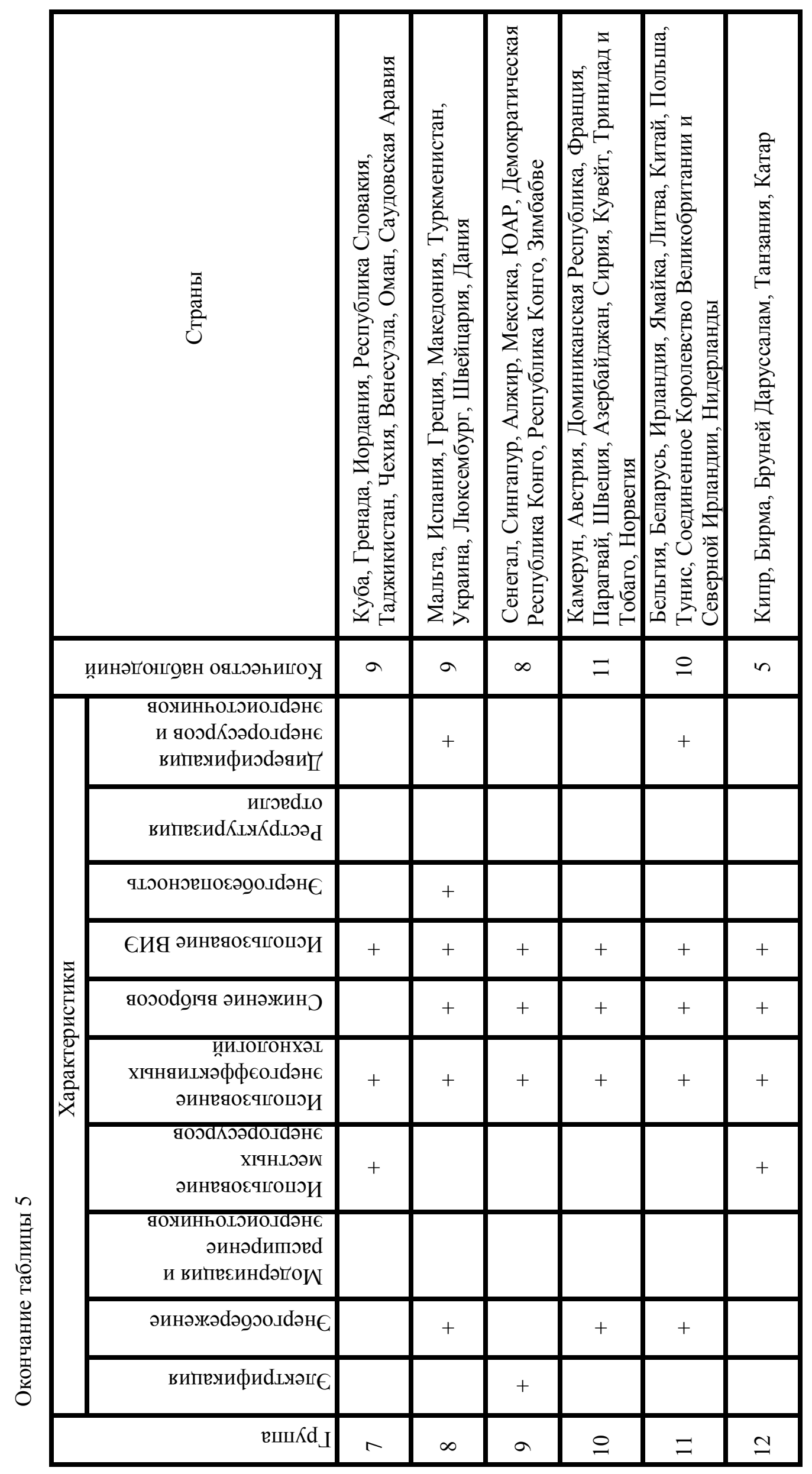


Таблица 6 - Предсказанная принадлежность к кластерам в процентах

\begin{tabular}{|c|r|r|r|r|r|r|r|r|r|r|r|r|}
\hline \multirow{2}{*}{ Кластер } & \multicolumn{10}{|c|}{ Предсказанная принадлежность к группе в \% } \\
\cline { 2 - 17 } & \multicolumn{1}{|c|}{2} & 3 & 4 & 5 & 6 & 7 & 8 & 9 & 10 & 11 & 12 \\
\hline 1 & 62,5 & 12,5 & 0 & 0 & 0 & 0 & 0 & 0 & 12,5 & 12,5 & 0 & 0 \\
\hline 2 & 7,1 & 78,6 & 0 & 14,3 & 0 & 0 & 0 & 0 & 0 & 0 & 0 & 0 \\
\hline 3 & 1,8 & 14,3 & 23,2 & 5,4 & 17,9 & 3,6 & 8,9 & 3,6 & 1,8 & 8,9 & 8,9 & 1,8 \\
\hline 4 & 5,7 & 14,3 & 5,7 & 22,9 & 5,7 & 11,4 & 2,9 & 11,4 & 8,6 & 2,9 & 5,7 & 2,9 \\
\hline 5 & 0 & 7,7 & 0 & 7,7 & 38,5 & 15,4 & 7,7 & 0 & 0 & 7,7 & 15,4 & 0 \\
\hline 6 & 0 & 0 & 0 & 0 & 0 & 100 & 0 & 0 & 0 & 0 & 0 & 0 \\
\hline 7 & 0 & 0 & 16,7 & 0 & 0 & 33,3 & 33,3 & 0 & 0 & 0 & 0 & 16,7 \\
\hline 8 & 0 & 0 & 0 & 0 & 0 & 0 & 0 & 100 & 0 & 0 & 0 & 0 \\
\hline 9 & 0 & 20 & 0 & 0 & 0 & 0 & 0 & 0 & 60 & 0 & 0 & 20 \\
\hline 10 & 0 & 0 & 0 & 0 & 0 & 0 & 0 & 0 & 0 & 100 & 0 & 0 \\
\hline 11 & 0 & 0 & 0 & 0 & 0 & 0 & 0 & 33,3 & 0 & 33,3 & 33,3 & 0 \\
\hline 12 & 0 & 0 & 0 & 0 & 0 & 0 & 0 & 0 & 0 & 0 & 0 & 100 \\
\hline
\end{tabular}

Таким образом, в результате проведенного дискриминантного анализа можно сделать вывод, что только 38,3\% исследуемых стран используют стратегии достижения устойчивого развития энергетики, свойственные своему кластеру, то есть стратегии соответствующие уровню экономического развития страны, учитывающие размер выбросов загрязняющих веществ в атмосферу, уровень электрификации страны и уровень запасов энергоресурсов.

Причин несоответствия принадлежности к кластерам и используемых стратегий стран несколько. Во-первых, некоторые страны ориентируются на общемировые тенденции в энергетике без учета своих особенностей, что часто приводит к невозможности реализации утвержденных на уровне государства программ в области энергетической политики. Во-вторых, часть стран использует стратегии лидеров, что не позволяет им уделять должное внимание решению своих первостепенных задач. В-третьих, при принадлежности к каким-либо союзам или ассоциациям страны обязуются выполнять определенные требования по энергетической политике данных объединений, что не всегда является экономически целесообразным при учете разнородности данных стран (например, страны ЕС). В-четвертых, отсутствует комплексный подход к формированию энергетической политики стран, что сказывается на невозможности оценки совокупного эффекта от реализации мероприятий.

На основе вышеизложенного, можно выделить несколько направлений совершенствования энергетической политики исследуемых стран: 1) необходимо разрабатывать специальные программные 
документы, касающиеся стратегий достижения устойчивого развития энергетики и средств их реализации в долгосрочном периоде; 2) при формулировании программных документов в области энергетики рекомендуется использовать четкие иерархии стратегий достижения устойчивого развития энергетики; 3) следует адаптировать стратегии достижения устойчивого развития энергетики к условиям функционирования конкретной страны.

Таким образом, по результатам кластерного и дискриминантного анализов было определено, что наиболее перспективными стратегиями достижения устойчивого развития энергетики Республики Беларусь с точки зрения мирового опыта являются энергосбережение, использование энергоэффективный технологий, снижение выбросов, использование ВИЭ, диверсификация энергоресурсов и энергоисточников.

Анализ сущчествуюших стратегий достижения устойчивого развития энергетики Республики Беларусь. Основным документом в области устойчивого развития Республики Беларусь является Национальная стратегия социально-экономического развития Беларуси до 2030 года [3], одобренная 15 февраля 2015 г. на заседании Президиума Совета Министров. Согласно данной стратегии, долгосрочной целью развития топливно-энергетического комплекса является удовлетворение потребностей экономики и населения страны в энергоносителях на основе их максимально эффективного использования при снижении нагрузки на окружающую среду.

На период до 2020 г. заявлены следующие задачи в области энергетики:

- реконструкция и модернизация действующих и замена выбывающих мощностей с внедрением инновационных энергоэффективных технологий;

- завершение модернизации нефтеперерабатывающих заводов и увеличение производства светлых нефтепродуктов с высокой добавленной стоимостью;

- формирование оптового электроэнергетического рынка Республики Беларусь и его интеграция в общий электроэнергетический рынок государств - членов Евразийского экономического союза (ЕАЭС);

- проведение политики, направленной на устранение неэкономических барьеров, обеспечение прозрачных, предсказуемых и гибких стимулов для развития возобновляемой энергетики [3].

В долгосрочной перспективе (2021-2030 годы) основной целью развития ТЭК станет повышение энергетической самостоятельности страны за счет вовлечения в энергобаланс ядерного топлива и ВИЭ. Предстоит расширить сотрудничество в рамках СНГ с ЕС, Китаем, 
международными организациями, способствующее трансферту технологий и системных решений в области энергоэффективности и использования ВИЭ.

Основная задача по повышению эффективности использования энергоресурсов - максимальное приближение Республики Беларусь к развитым странам по уровню энергоемкости валового внутреннего продукта как главного энергетического критерия развития экономики страны. В настоящее время он в 1,5-2 раза превышает аналогичный показатель экономически развитых стран, в 1,5 раза - стран-членов Организации экономического сотрудничества и развития (ОЭСР).

Согласно Национальной стратегии социально-экономического развития Беларуси до 2030 года, не теряет своей остроты проблема загрязнения воздушного бассейна крупных городов (выбросы $\mathrm{CO}_{2}$ на одного жителя в Республике Беларусь в результате потребления энергоресурсов в 2011 году составили 6,97 т, что выше общемирового значения в 4,5 т и чем в соседних странах: Литве $(4,13)$, Латвии $(3,41)$ и Украине $(6,24)$, но в то же время существенно ниже, чем в странах ОЭСР $(9,95)$, России $(11,65)$ и Казахстане $(14,14))$. Планируется, что модернизация энергоисточников, переход на использование натуральных хладагентов сократят потребление энергоресурсов и уменьшат экологическую нагрузку на окружающую среду за счет снижения выбросов $\mathrm{CO}_{2}$, диоксида азота и парниковых газов в атмосферу [3].

Следовательно, можно выделить следующие направления устойчивого развития энергетики Республики Беларусь в период 2015-2030 г.:

1) энергосбережение и внедрение энергоэффективных технологий;

2) диверсификация энергоресурсов и энергоисточников за счет использования ВЭИ и использования атомной энергии;

3) формирование оптового электроэнергетического рынка;

4) снижение выбросов загрязняющих веществ в атмосферу.

Следует отметить, что Республикой Беларусь уже сделаны определенные шаги на пути реализации указанных стратегий в более ранние периоды, однако не всегда удавалось достичь целей, заявленных в программных документах, в полном объеме.

Однако, следует отметить, что многие из плановых показателей, касающихся реализации стратегий энергосбережения, диверсификации энергоресурсов и энергоисточников за счет использования ВИЭ и местных энергоресурсов, формирования оптового электроэнергетического рынка, а также увеличения глубины переработки нефти, не были достигнуты либо с учетом текущих тенденций не будут достигнуты к намеченным срокам. 
Данная ситуация объясняется несколькими обстоятельствами:

1) недостаток финансирования программ по энергосбережению и энергоэффективности. Согласно информации Департамента по энергоэффективности Государственного комитета по стандартизации Республики Беларусь (Департамент по энергоэффективности), достижение установленных показателей по энергосбережению в 2011 - 2015 годах потребует финансирования мероприятий по повышению эффективности использования энергоресурсов и увеличению доли использования местных видов топлива в объеме 8,66 млрд. долл. США. В структуре финансирования энергоэффективных мероприятий в качестве основных источников планируются собственные средства предприятий (порядка $38 \%$ в общем объеме), кредиты банков, займы и другие привлеченные средства (порядка $20 \%$ ). Государственная поддержка в виде долевого участия за счет средств республиканского и местных бюджетов $(22 \%$ в объеме финансирования), отраслевых инновационных фондов (20\%) будет оказываться организациям социальной и бюджетной сферы, а также другим организациям для внедрения наиболее эффективных мероприятий по приоритетным направлениям энергосбережения [1].

2) снижение повышающих коэффициентов к тарифам на электрическую энергию, производимую из некоторых ВИЭ. В Республике Беларусь электрическая энергия из ВИЭ продвигается, главным образом, посредством использования так называемой системы тарифов с применением повышающих коэффициентов. Согласно постановлению Министерства экономики Республики Беларусь от 30 июня 2011 года № $100 \ll \mathrm{O}$ тарифах на электрическую энергию, производимую из возобновляемых источников энергии, и признании утратившими силу некоторых постановлений Министерства экономики Республики Беларусь», на первые 10 лет с момента ввода установок по использованию возобновляемых источников энергии в эксплуатацию устанавливаются повышающие коэффициенты в размере 1,3. Исключением являются установки, использующие солнечную энергию - для них установлен повышающий коэффициент 3. На последующие 10 лет для всех видов установок устанавливаются стимулирующие коэффициенты в размере 0,85 [6]. Однако в 2014 г. данные коэффициенты для электрической энергии из некоторых видов ВИЭ были снижены. В соответствии с постановлением Министерства экономики Республики Беларусь от 8 апреля 2014 г. № 29 «О внесении изменений в постановление Министерства экономики Республики Беларусь от 30 июня 2011 г. № 100» на первые 10 лет с момента ввода установок по использованию энергии естественного движения водных потоков в эксплуатацию повышающий коэффициент установлен в размере 1,1 против коэффициента 1,3 , 
действовавшего ранее. Для установок, использующих солнечную энергию, коэффициент снижен до 2,7 с 3, установленного ранее [5].

3) отсутствие необходимой нормативно-правовой базы для формирования оптового электроэнергетического рынка. В феврале 2014 г. была одобрена только концепция закона «Об электроэнергетике» [2]. Принятие концепции закона создаст предпосылки для разделения потенциально конкурентных и монопольных видов экономической деятельности, перехода на самоокупаемость, формирования оптового и розничного электроэнергетических рынков в целях конкуренции субъектов электроэнергетики и сочетания регулируемых и свободных цен, а также ухода от перекладывания затрат с одного вида экономической деятельности на другой и (или) потребителей (уход от перекрестного субсидирования). Принятие закона будет способствовать в том числе повышению уровня энергобезопасности, реализации основных принципов формирования общего электроэнергетического рынка государств участников СНГ, гармонизации законодательства Республики Беларусь с ее международными обязательствами.

4) значительный объем финансирования для модернизации нефтеперерабатывающих заводов. Согласно стратегии развития энергетического потенциала Республики Беларусь, объем финансирования реализации программ развития нефтеперерабатывающих заводов составит:

- ОАО «Нафтан» - 4,1 трлн руб., из них кредиты банков (в том числе иностранные) - 2,7 трлн руб.;

- ОАО «Мозырский НПЗ»- 3,4 трлн руб., из них кредиты банков (в том числе иностранные) - 2 трлн руб. [4].

В то же время некоторые из плановых показателей не только были достигнуты, но и перевыполнены (объем производства и экспорта брикетов топливных) либо с учетом текущих тенденций должны быть достигнуты к намеченному сроку (доля природного газа в валовом потреблении энергоресурсов).

Таким образом, на период до 2030 г. приоритетными стратегиями достижения устойчивого развития энергетики Республики Беларусь являются:

1) энергосбережение и внедрение энергоэффективных технологий;

2) использование ВИЭ;

3) использование атомной энергии;

4) формирование оптового электроэнергетического рынка (данный процесс во многом стимулируется Евразийской интеграцией);

5) снижение выбросов загрязняющих веществ в атмосферу.

При этом следует отметить, что не все стратегии достижения устойчивого развития в равной степени применимы для всех отраслей энергетики Республики Беларусь (таблица 7). 
Таблица 7 - Приоритетные стратегии достижения устойчивого развития для различных отраслей энергетики

\begin{tabular}{|c|c|c|c|c|c|c|}
\hline Отрасли & 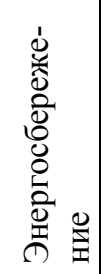 & 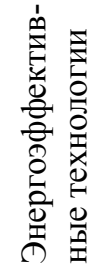 & 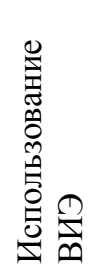 & 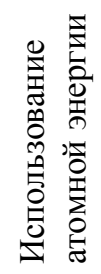 & 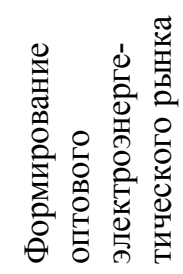 & 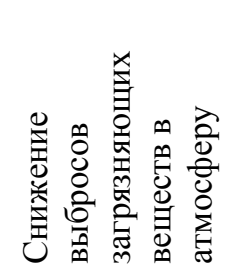 \\
\hline Нефтяная & + & + & + & & & + \\
\hline Газовая & + & + & + & & & + \\
\hline Торфяная & + & + & & & & + \\
\hline Электроэнергетика & & + & + & + & + & + \\
\hline
\end{tabular}

Как видно из таблицы 7, наибольшее количество стратегий достижения устойчивого развития касаются электроэнергетики (5 из 6). Для нефтяной, газовой и топливной отраслей до 2030 г. планируется использование таких стратегий достижения устойчивого развития как энергосбережение, использование энергоэффективных технологий и снижение выбросов загрязняющих веществ в атмосферу. Кроме того, для нефтяной и газовой отраслей рекомендовано использование стратегии использования ВИЭ. Следует отметить, что данная стратегии, наряду со стратегией снижения выбросов загрязняющих веществ в атмосферу является перспективной для всех отраслей энергетики Республики Беларусь.

Заключение. Наиболее перспективными стратегиями достижения устойчивого развития энергетики Республики Беларусь с точки зрения мирового опыта являются энергосбережение, использование энергоэффективный технологий, снижение выбросов, использование ВИЭ, диверсификация энергоресурсов и энергоисточников.

В то же время, приоритетными стратегиями достижения устойчивого развития энергетики Республики Беларусь согласно Национальной стратегии социально-экономического развития Беларуси до 2030 года являются: энергосбережение и внедрение энергоэффективных технологий; использование ВИЭ; использование атомной энергии; формирование оптового электроэнергетического рынка (данный процесс во многом стимулируется Евразийской интеграцией); снижение выбросов загрязняющих веществ в атмосферу.

Таким образом, на основе проведенного исследования можно сделать вывод о соответствии стратегии устойчивого энергетического развития Республики Беларусь мировым тенденциям, а следовательно, высокой эффективности государственной политики к отношении развития энергетического сектора. 


\section{ЛИТЕРАТУРА}

1. Департамент по энергоэффективности Государственного комитета по стандартизации Республики Беларусь // [Электронный ресурс]. - Режим доступа: http://energoeffekt.gov.by/. - Дата доступа: 30.10.2015.

2. Концепция закона «Об электроэнергетике» одобрена в Правительстве Беларуси // БЕЛТА [Электронный ресурс]. - Режим доступа: http://www.belta.by/economics/view/kontseptsija-zakona-ob-elektro energetike-odobrena-v-pravitelstve-belarusi-35776-2014. - Дата доступа: 30.10.2015.

3. Национальная стратегия устойчивого социально-экономического развития Республики Беларусь на период до 2030 года / ГНУ НИЭИ // Экономический бюллетень НИЭИ Министерства экономики Республики Беларусь. - № 4 (214). - С. 6-99.

4. Об утверждении стратегии развития энергетического потенциала Республики Беларусь: постанов. Совета Министров Респ. Беларусь, 9.08.2010, № 1180 // Нац. реестр правовых актов Респ. Беларусь. - 2010. № 198 . $-5 / 32338$.

5. О внесении изменений в постановление Министерства экономики Республики Беларусь от 30 июня 2011 г. № 100: постанов. Министерства экономики Респ. Беларусь, от от 8 апреля 2014 г., № 29 // Нац. реестр правовых актов Респ. Беларусь. - 2014. - 8/28632.

6. О тарифах на электрическую энергию, производимую из возобновляемых источников энергии, и признании утратившими силу некоторых постановлений Министерства экономики Республики Беларусь: Постановление Министерства экономики Беларуси от 30 июня 2011 г., № 100 // Национальный реестр правовых актов Республики Беларусь. 2011. - 8/23974.

7. Clean Energy Search. Energy framework [Electronic resource] / Reegle. - Mode of access: www.reegle.info. - Date of access: 20.12.2014.

8. International Energy Agency // [Electronic resource]. - Mode of access: http://www.iea.org/. - Date of access: 08.10.2015.

9. The World Bank // [Electronic resource]. - Mode of access: http://data.worldbank.org/. - Date of access: 08.10.2015.

10. World Statistics // [Electronic resource]. - Mode of access: http://world-statistics.org/. - Date of access: 08.10.2015.

Статья поступила в редакиию 24 октября 2016 года. 